\title{
White spot syndrome virus (WSSV) infection in tiger shrimp Penaeus monodon: A non-lethal histopathological rapid diagnostic method using paraffin and frozen sections
}

\author{
K.V. RAJENDRAN ${ }^{1}$, K.K. VIJAYAN ${ }^{2, *}$, T.C. SANTIAGO ${ }^{2}$ and \\ J.J.S. RAJAN ${ }^{2}$ \\ ${ }^{1}$ Central Institute of Fisheries Education, 7 Bungalows, Versova, Mumbai, India; ${ }^{2}$ Central Institute of \\ Brackishwater Aquaculture, 75 Santhome High Road, R.A. Puram, Chennai-600028, India; *Author \\ for correspondence (e-mail: kkvijayan@hotmail.com; phone: +91-44-24618817; fax: +91-44- \\ 24610311)
}

Received 15 July 2003; accepted in revised form 22 November 2004

Key words: Early diagnostic method, Frozen sections, Histopathology, Non-lethal, Penaeus monodon, White spot syndrome virus (WSSV)

Abstract. White spot syndrome virus (WSSV) infection was induced in tiger shrimp, Penaeus monodon, under laboratory conditions, and histopathological changes in subcuticular epithelial cells of the eye stalk and pleopod were studied sequentially at different time post-challenge. Routine histological techniques using paraffin embedded tissues, as well as frozen tissues, were used to document WSSV infection. Histological manifestations such as cellular hypertrophy in the subcuticular epithelial cells of the eyestalk and pleopod could be detected as early as $18 \mathrm{~h}$ postinfection (p.i.) before the manifestation of clinical signs of the disease. However, no histopathological changes could be detected before $18 \mathrm{~h}$ p.i.. Hypertrophy of the nuclei in the epithelial cells was pronounced after $24 \mathrm{~h}$ p.i. Marked necrosis, and eosinophilic intranuclear inclusions, characteristic of early stages of WSSV infection were observed between 24-36 h p.i. Clinical signs of the disease appeared at $48 \mathrm{~h}$ p.i. The presence of WSSV at early asymptomatic stages of p.i. has been tested in parallel samples using polymerase chain reaction, for further confirmation of WSSV. This paper discusses the potential of a non-lethal and rapid histopathological diagnostic method to document WSSV infection, using the eyestalk or pleopod, when expensive DNA based diagnostics are not available or affordable.

\section{Introduction}

During the last few years, white spot disease (WSD) has spread worldwide and caused large-scale mortalities and severe damage to shrimp culture, particularly in Asia leading to massive economic losses (Lightner 1996; Flegel 1997). The causative organism has been identified as a bacilliform virus, widely known as white spot syndrome virus (WSSV) (Lightner 1996). White spot syndrome virus is the most virulent and the largest animal virus known to affect cultured shrimp (Van Hulten et al. 2001). In the absence of an effective treatment against the WSSV, preventive measures using early and rapid diagnostics has a crucial role in the management of WSD. 
DNA-based novel diagnostic tools, such as PCR, and immunological methods, such as monoclonal antibodies (MAbs), have already been developed, and are being used as health management tool (Lightner 1996). However, these diagnostic tools are expensive and require sophisticated laboratory support. A non-lethal, rapid and cost-effective method, which can be performed in an ordinary laboratory, can be useful in routine health monitoring. Hence an effort has been made to study and compare the use of the classical histopathological method and polymerase chain reaction (PCR), in the early diagnosis of WSSV.

Histopathological evidence has shown that this virus replicates in tissues of ectodermal and mesodermal origin only (Chou et al. 1995; Lightner 1996; Karunasagar et al. 1997; Mohan et al. 1997; Rajendran et al. 1999, Yoganandhan et al. 2003; Vijayan et al. 2003). Evidence of histopathological manifestations in the target tissues is one of the criteria used in the diagnosis of WSSV infection (Lightner 1996; Wang et al. 1997). During our investigation on the histopathology of the WSSV infection, we have noticed obvious histological changes characteristic of WSSV in the cuticular epidermis of eyestalk and pleopod (Rajendran et al. 1998, 1999), which is in agreement with the observation of Chang et al. 1996 and Lo et al. 1997. Epithelial cells of the eyestalk and pleopod are the preferred tissues of WSSV, and the initial sites of viral infection (Chang et al. 1996; Lo et al. 1997). This paper describes the sequential pathological changes in the eye stalk and pleopod tissue of WSSV-infected tiger shrimp, Penaeus monodon, and the possibility of using histological and frozen sections of these tissues as a non-lethal histological technique for an early diagnosis of the disease, when the DNA-based diagnostic (Chang et al. 1996; Durand et al. 1996; Tapay et al. 1999) facilities are not available, or affordable.

\section{Materials and methods}

\section{Collection of experimental animals}

Healthy sub-adults of $P$. monodon, $(8-12 \mathrm{~g})$, were collected from a farm located near Chennai, Tamil Nadu, India, without any previous history of white spot disease. These shrimp were kept in 1000-1 fiberglass tanks and acclimatized for one week (salinity $20-25 \mathrm{ppt}$; ambient temperature $28-30^{\circ} \mathrm{C}$; $\mathrm{pH} 8.0-8.20$ ). The shrimp were fed artificial pelleted feed (35\% protein). The experimental animals were screened (20 random shrimps from a group of 200) for white spot virus using PCR (Takahashi et al. 1996). After screening, a total of 120 healthy animals were used in this experiment.

\section{Preparation of viral inoculum}

Samples of WSSV were collected from two farms at Nellore, Andhra Pradesh, India, during an epizootic in 1999. Tissue samples from the gills, stomach and 
epidermal layer were prepared from the infected samples and stored at $-80^{\circ} \mathrm{C}$. These samples were subsequently used to induce the disease, following the method of Takahashi et al. (1994). The infected tissues were homogenized in sterile marine phosphate buffered saline (PBS), centrifuged at $2000 \mathrm{rpm}$ at $4{ }^{\circ} \mathrm{C}$ for $10 \mathrm{~min}$, and the supernatant was filtered through a $0.45-\mu \mathrm{m}$ filter fitted to a syringe. The filtrate was diluted $(1: 100)$ and injected into the second abdominal muscle of healthy shrimp $(0.1 \% \mathrm{v} / \mathrm{w})$. A negative control group was maintained by injecting sterile marine PBS intramuscularly into healthy shrimp.

\section{Experimental infection and sequential pathology}

Sampling was performed at $6,12,18,24,36,48$ and $72 \mathrm{~h}$ post-challenge. Three 500-1 fiberglass tanks were filled with filtered seawater with salinity between 20 and $25 \mathrm{ppt}$, ambient temperature of $28-30^{\circ} \mathrm{C}$ and $\mathrm{pH} 8.0-8.2$. Each tank was stocked with 40 experimental shrimp. The replicated treatment groups were kept in tanks 1 and 2, while the third tank held the negative control. Inoculum of WSSV was administered intramuscularly using $1 \mathrm{ml}$ tuberculin syringe fitted with a 22-gauge needle. At each collection time, three animals were removed from the replicate and the control groups (one each for normal histology using paraffin sections, frozen and PCR method of diagnosis).

\section{Histology}

The eyestalk (left eyestalk without compound eye) and pleopod (one of the fourth pair) were excised aseptically using standard biopsy procedures (Bell et al. 1990) and immediately fixed by submersion in Davidson's fixative. Similarly, the eyestalk and pleopod were removed for the preparation of cryosections and PCR, respectively. Histological observations were made according to the procedure outlined by Bell and Lightner (1988). Sections of 5-6 $\mu \mathrm{m}$ thickness were stained with hematoxylin and eosin (H\&E).

For rapid processing of tissues, frozen sections were cut using a Leica CM 1800 Cryostat as per the following procedure. Fresh tissues excised from normal and experimentally-infected shrimp were placed in tissue embedding medium (Leica, OCT cryo embedding medium supplied by Leica, Germany), then kept in the freezing chamber at -18 to $-20^{\circ} \mathrm{C}$ for $35 \mathrm{~min}$, and sectioned at $6-8 \mu \mathrm{m}$ thickness. Sections were attached to warm slides and air-dried. These sections were fixed in chilled acetone and stained with Rapid H\&E (Culling 1985). Photomicrographs of frozen and paraffin slides stained with H\&E were taken using a WILS MPS 46 camera fitted to a Leitz Laborlux S microscope.

\section{Polymerase chain reaction}

WSSV infection at different time points was confirmed by PCR technique. Template DNA was extracted following the procedures of Vijayan et al. (1998) 


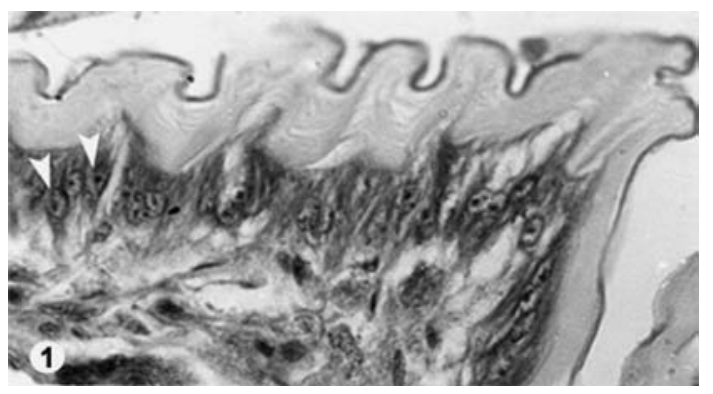

Figure 1. Cuticular epithelium of a healthy (control) P. monodon eyestalk. Arrow indicates the normal subcuticular epithelial cells with normal nuclei. Paraffin section $-\mathrm{H}$ and E, 1000x.

from the eyestalks (without compound eye) and pleopods removed from infected and control shrimp at various time intervals. The PCR was carried out according to Takahashi et al. (1996) to detect WSSV infection. PCR products were electrophoresed in $0.8 \%$ agarose gel stained with ethidium bromide, and visualized under ultraviolet transillumination.

\section{Results}

The WSSV-induced pathological changes were detected in the subcuticular epithelial cells of the eyestalk and pleopod in clinically normal shrimp, as early as $18 \mathrm{~h}$ post-infection (p.i.). At this time point, the nuclei of the epithelium showed discernible hypertrophy (Figures 2 and 3), while the control tissues showed normal cell architecture (Figure 1). Nuclear hypertrophy, central chromatin diminution and margination were distinct in the WSSV infected cells. No indication of a WSSV infection was detected at any earlier time point. As infection progressed, hypertrophied nuclei containing intranuclear, eosinophilic inclusions, characteristic of the early stage of WSSV infection, were noticed at 24 and $36 \mathrm{~h}$ p.i. Mortality and other clinical signs of the disease were detected in the experimental animals only after $48 \mathrm{~h}$ p.i. The appearances of white spots over the exoskeleton, pinkish-red body color, lethargy and anorexia are the common clinical signs associated with the WSSV. Shrimp that survived up to $48 \mathrm{~h}$ p.i. showed marked lesions in the subcuticular epithelial cells in which numerous, large, highly basophilic inclusion bodies were seen (Figures 4 and 5).

Results of the electrophoresis of the PCR products of various post-infection stages and positive and negative controls are given in Figure 6. Using PCR, WSSV infection could be diagnosed as early as $6 \mathrm{~h}$ p.i., demonstrated by a consistent amplification of the WSSV-DNA (643 bp) from the eyestalk and pleopod collected from shrimp at 6-72 h p.i. The negative control group was PCR-negative.

Observation of the paraffin and frozen sections in the present study showed that the cellular changes observed in both procedures are comparable in terms 


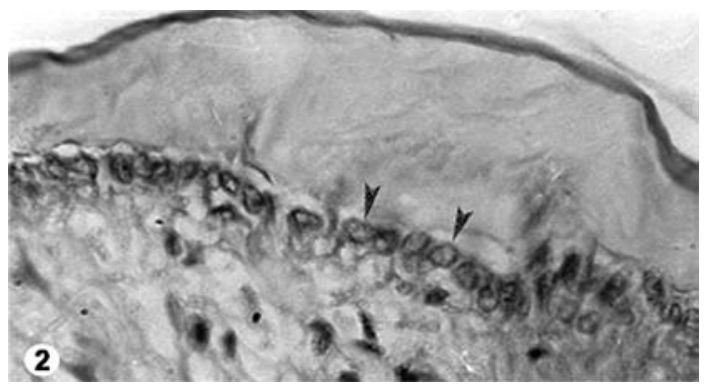

Figure 2. Cuticular epithelium of the eyestalk of P. monodon experimentally infected with WSSV, $18 \mathrm{~h}$ post-infection, arrow shows hypertrophied nuclei. Paraffin section $-\mathrm{H}$ and E, 1000×.

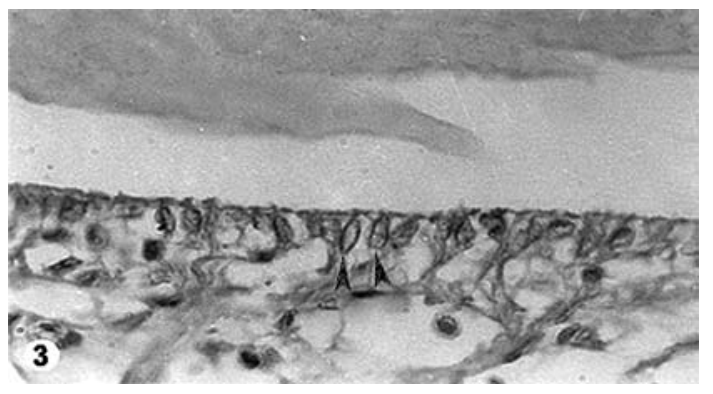

Figure 3. Cuticular epithelium of the eyestalk of experimentally infected P. monodon with WSSV, $18 \mathrm{~h}$ post-infection, arrow shows hypertrophied nuclei. Frozen section $-\mathrm{H}$ and E, 1000x

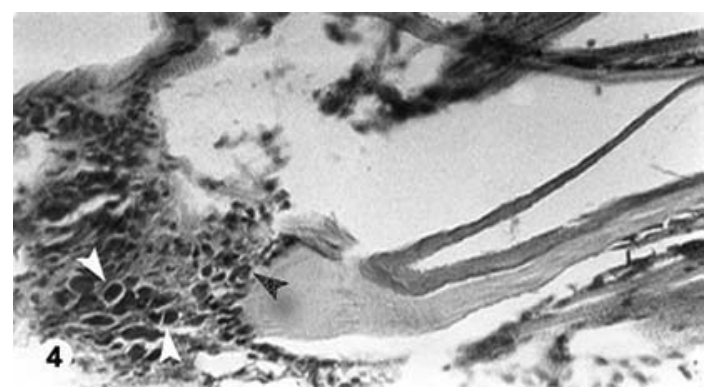

Figure 4. Cuticular epithelium of the pleopod of experimentally infected P. monodon with WSSV, $72 \mathrm{~h}$ post-infection. Arrow shows degenerated and heavily infected cuticular epithelial cells showing large basophilic inclusions characteristic of WSSV infection. Paraffin section $-\mathrm{H}$ and E, 400×.

of histological changes, which were subsequently used for WSSV diagnosis (Figures 2-5). By using routine paraffin sections, a conclusive diagnosis was obtained at $48-72 \mathrm{~h}$ post-sampling, whereas the histological procedure adopted in the present study using frozen sections and rapid H\&E staining was completed in $4 \mathrm{~h}$, enabling an early diagnosis. The discernible histopathological 


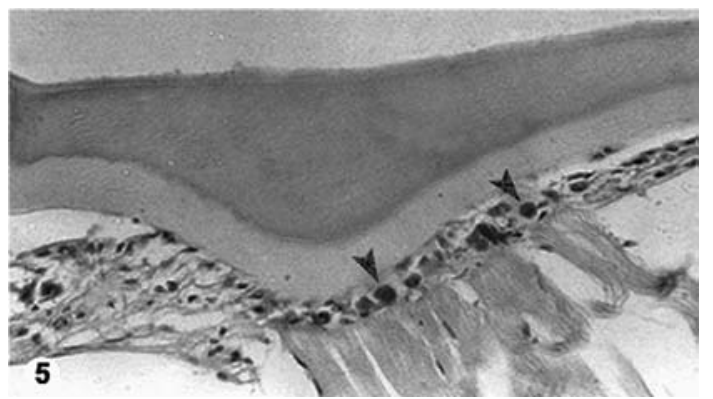

Figure 5. Cuticular epithelium of the pleopod of experimentally infected P. monodon with WSSV, $72 \mathrm{~h}$ post-infection. Arrow shows degenerated and heavily infected cuticular epithelial cells showing large basophilic inclusions characteristic of WSSV infection, Frozen section - H and E, 400×.

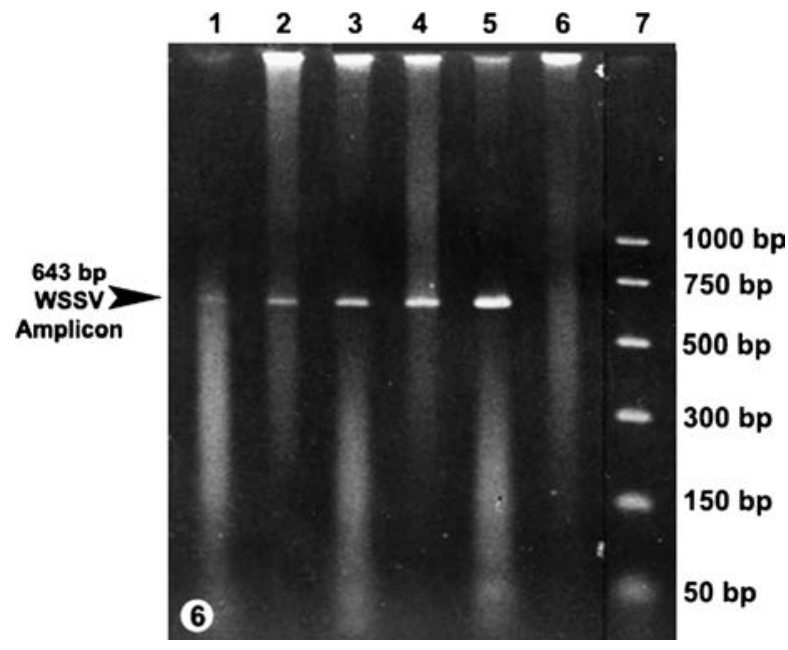

Figure 6. Electrophoretic pattern of PCR product. Pleopods collected at different time points of post-infection from $P$. monodon experimentally infected with WSSV have been used as the source of template DNA. Lanes 1-4 correspond to $6,12,18$ and $24 \mathrm{~h}$ post-infection, respectively; lane 5 corresponds to positive control; lane 6 negative control and lane 7 molecular weight markers (Samples from 36, 48 and $72 \mathrm{~h}$ were not included).

manifestations, as early as $18 \mathrm{~h}$ p.i., indicated that the WSSV infection could be detected before the manifestation of clinical signs of the disease, though the diagnosis was not as specific and sensitive as PCR (Table 1).

\section{Discussion}

We selected the eyestalk and pleopod as the target tissues for WSSV detection, for two reasons. First, pleopod and eyestalk consisted of subcuticular epithelial 
Table 1. Detection of WSSV in the eyestalk and pleopod using sequential pathology and PCR, in experimentally infected P. monodon.

\begin{tabular}{|c|c|c|c|c|c|}
\hline p.i. & Clinical condition & $\begin{array}{l}\text { WSSV detection by } \\
\text { paraffin sections }\end{array}$ & $\begin{array}{l}\text { WSSV detection by } \\
\text { frozen sections }\end{array}$ & $\begin{array}{l}\text { WSSV detection } \\
\text { by PCR }\end{array}$ & Mortality \\
\hline $0 \mathrm{~h}$ & Normal & Negative & Negative & Negative & Nil \\
\hline $6 \mathrm{~h}$ & Normal & Negative & Negative & Positive & Nil \\
\hline $12 \mathrm{~h}$ & Normal & Negative & Negative & Positive & Nil \\
\hline $18 \mathrm{~h}$ & Normal & Positive $(+)$ & Positive $(+)$ & Positive & Nil \\
\hline $24 \mathrm{~h}$ & Normal & Positive (+) & Positive $(+)$ & Positive & Nil \\
\hline $36 \mathrm{~h}$ & Normal & Positive $(++)$ & Positive $(++)$ & Positive & Nil \\
\hline $48 \mathrm{~h}$ & Lethargic, Anorexia & Positive $(+++)$ & Positive $(+++)$ & Positive & Yes \\
\hline $72 \mathrm{~h}$ & $\begin{array}{l}\text { Lethargic; Anorexia, } \\
\text { Moribund, } \\
\text { Pale reddish color; } \\
\text { White spots }\end{array}$ & Positive $(+++)$ & Positive $(+++)$ & Positive & Yes \\
\hline \multicolumn{6}{|c|}{ Control groups } \\
\hline
\end{tabular}

p.i., Post-infection time; + , Early infection; ++ , Advance infection; +++ , Severe infection.

cells, which are one of the target tissues of this virus. Nash and Akarajamorn (1995) and Chang et al. (1996) have reported that cuticular epithelial cells are one of the most preferred sites of the WSSV, and among the first sites the virus sets in. Second, removal of a pleopod or eyestalk is not harmful to the shrimp, hence can be used for non-lethal diagnosis in the screening of WSSV. When eyestalk removal is carried out to induce maturation, the stalk of the removed eye can be used for the diagnosis of WSSV. When eyestalks are not available, as in the case of gravid females or hatchery-reared broodstock, pleopods can be used. Removal of one of the pleopods did not hamper the maturation process or the health status of the shrimp, if the standard excision methods are followed.

The cellular pathology of WSSV infected P. monodon observed in the present study is in agreement with the observation of Nash and Akarajamorn (1995), Chang et al. (1996) and Yoganandhan et al. (2003). At the very early asymptomatic and subclinical stages of infection, up to $18 \mathrm{~h}$ p.i., only the PCR gave positive results, indicating the sensitivity and advantage of PCR over histological methods. This is the case in broodstock screening and quarantine checks, where a distinct histomorphological manifestation is absent, and hence PCR is the preferred diagnostic choice. However, from $18 \mathrm{~h}$ p.i., the majority of the subcuticular epidermal cells showed nuclear hypertrophy and chromatin diminution and margination, characteristic of WSSV infection. In shrimp viral infections other than WSSV, the nuclear hypertrophy, chromatin diminution and margination were not distinct and uniform among the subcuticular epidermis (Lightner 1996). The present observations on the sequential histological changes in the tissues of the eyestalk and pleopod revealed that these tissues could be used for an early diagnosis of WSSV infection. Therefore, it is suggested that in situations where the DNA-based diagnostic techniques are not 
available or affordable due to high operating cost, the histological method using frozen sections could be a useful tool, as diagnosis can be made within $4 \mathrm{~h}$. Further, in the epidemiological studies, where the sensitivity level of PCR is not required, the rapid histological diagnosis using frozen sections and rapid staining can be used. Histopathology on frozen sections has been a routine practice in human as well as animal diagnostics. However, in aquatic animal health, where histopathological diagnostic forms an important tool, the potential of cryosections has not been explored in any detail. The present report is the first attempt to use cryosections as a rapid histopathological diagnostic in shrimp health.

Screening of broodstock shrimp for WSSV is one of the effective ways to check the vertical transmission of disease through the hatcheries (Hsu et al. 1999). Monitoring of WSSV in the grow-out ponds has been suggested as one of the health monitoring methods in the farming of shrimp (Peng et al. 2001). The present study has indicated that histomorphological changes in the subcuticular ectoderm of eyestalk and pleopod has diagnostic potential, and can be used as a non-lethal and rapid diagnostic tool for the routine screening of shrimp broodstock and farm reared stocks.

\section{Acknowledgements}

The authors are grateful to Director, C.I.B.A., for providing facilities and encouragement. The second author (KKV) is thankful to the Department of Biotechnology, Govt. of India, for the DBT Overseas Associateship.

\section{References}

Bell T.A. and Lightner D.V. 1988. A Handbook of Normal Penaeid Shrimp histology. World Aquaculture Society, Baton Rouge, LA, pp. 114.

Bell T.A., Lightner D.V. and Brock J.A. 1990. A biopsy procedure for the non-destructive determination of IHHNV infections in Penaeus vannamei. J. Aquat. Anim. Health 2: 151-153.

Chang P.S., Lo C.F., Wang Y.C. and Kou G.H. 1996. Identification of white spot syndrome associated baculovirus (WSBV) target organs in the shrimp Penaeus monodon by in situ hybridization. Dis. Aquat. Organ. 27: 131-139.

Chou H.Y., Huang C.V., Wang C.H., Chiang C.H. and Lo C.F. 1995. Pathogenicity of a baculovirus infection causing white spot syndrome in cultured penaeid shrimp in Taiwan. Dis. Aquat. Organ. 23: 165-173.

Culling C.F.A. 1985. Cellular Pathology Techniques. Butterworth \& Co., Somerset, UK pp.144 145.

Durand S., Lightner D.V., Nunan L.M., Redman R.M., Mari J. and Bonami J.R. 1996. Application of gene probes as a diagnostic tool for white spot baculovirus (WSBV) in penaeid shrimp. Dis. Aquat. Organ. 27: 59-66.

Flegel T.W. 1997. Special topic review: major viral diseases of the black tiger prawn (Penaeus monodon) in Thailand. World J. Microbiol. Biotechnol. 13: 433-442. 
Hsu H.C., Lo C.F., Liu K.F., Su M.S. and Kou G.H. 1999. Studies on effective PCR screening strategies for white spot syndrome virus (WSSV) detection in Penaeus monodon brooders. Dis. Aquat. Organ. 39: 13-19.

Karunasagar I., Otta S.K. and Karunasagar I. 1997. Histopathological and bacteriological study of white spot syndrome in Penaeus monodon along the west coast of India. Aquaculture 153: 9-13.

Lightner D.V. 1996. A Handbook of Shrimp Pathology and Diagnostic Procedures for Diseases of Cultured Penaeid Shrimp. World Aquaculture Society, Baton Rouge, Lousiana, USA, 304 pp.

Lo C.F., Ho C.H., Chen C.H., Liu K.F., Chiu Y.L., Yeh P.Y., Peng S.E., Hsu H.C., Liu H.C., Chang C.F., Su M.S., Wang C.H. and Kou G.H. 1997. Detection and tissue tropism of white spot syndrome baculovirus (WSBV) in captured brooders of Penaeus monodon with a special emphasis on reproductive organs. Dis. Aquat. Organ. 30: 53-72.

Mohan C.V., Sudha P.M., Shankar K.M. and Hegde A. 1997. Vertical transmission of white spot baculovirus in shrimps a possibility? Curr. Sci. 73: 109-110.

Nash G. and Akarajamorn A. 1995. Sequential histopathology of systemic ectodermal and mesodermal baculovirus infection in Penaeus monodon Fabricius. Asian Shrimp News 3: 2.

Peng S.E, Lo C.F., Lin S.C., Chen L.L., Chang Y.S., Liu K.F., Su M.S. and Kou G.H. 2001. Performance of WSSV-infected and WSSV-negative Penaeus monodon postlarvae in culture ponds. Dis. Aquat. Organ. 46: 165-172.

Rajendran K.V., Vijayan K.K., Alavandi S.V., Rangaswami C.P., Srinivasagm S. and Rajabau D. 1998. White spot disease outbreak in confined rainfed shrimp culture ponds of Chilka lake: a case study. J. Aquacult. 6: 43-47.

Rajendran K.V., Vijayan K.K. and Santiago T.C. 1999. Experimental host range and histopathology of white spot syndrome virus (WSSV) in shrimps, prawns, crabs and lobsters from India with a note on the carrier/reservoir hosts. J. Fish Dis. 22: 183-191.

Takahashi Y., Itami T., Kondo M., Maeda M., Fiji S., Tomonaga K., Supamattaya K. and Boonyaratpalin S. 1994. Electron microscopic evidence of bacilliform virus infection in Kuruma shrimp (Penaeus japonicus). Fish Pathol. 29: 121-125.

Takahashi Y., Itami T., Maeda M., Suzuki, N., Kasornchandra J., Supamattaya K., Khongpradit R., Boonyaratpalin S., Kondo M., Kawai K., Kusude R., Hirono, I. and Aoki T. 1996. Polymerase chain reaction (PCR) amplification of bacilliform virus (RVPJ) DNA in Penaeus japonicus Bate and systemic ectodermal and mesodermal baculovirus (SEMBV) DNA in Penaeus monodon Fabricius. J. Fish Dis. 19: 399-403.

Tapay L.M., Cesar E., Nadala E.C.B. Jr. and Loh P.C. 1999. A polymerase chain reaction (PCR) protocol for the detection of various geographical isolates of white spot virus (WSV). J. Virol. Methods 82: 39-43.

Van Hulten M.C., WittevelPeters S., Kloosterboer N., Tarchini R., Fiers M., Sandbrink H., Lankhorst R.K. and Vlak J.M. 2001. The white spot syndrome virus DNA genome sequence. Virology 286: 7-22.

Vijayan K.K., Rajendran K.V. and Santiago T.C. 1998. A simple and rapid molecular diagnostic technique for white spot syndrome virus (WSSV) infection. In: Balachandran K.K. (ed.), Advances and Priorities in Fisheries Technology. Society of Fisheries Technologists (India), Cochin, pp. 398-401.

Vijayan K.K., Balasubramanian C.P., Jithendran K.P., Alavandi, S.V. and Santiago T.C. 2003. Histopathology of Y-organ in Indian white shrimp Fenneropenaeus indicus, experimentally infected with white spot syndrome virus. Aquaculture 221: 97-106.

Wang C.S., Tang K.F.J., Kou G.H. and Chen S.N. 1997. Light and electron microscopic evidence of white spot syndrome (WSBV) of Penaeus monodon. J. Fish Dis. 20: 323-331.

Yoganandhan K., Sathish S., Murugan V., Narayanan R.B. and Sahul Hameed A.S. 2003. Screening the organs for early detection of white spot syndrome virus in Penaeus indicus by histopathology and PCR techniques. Aquaculture 215: 21-29. 